\title{
Regional Competitiveness for Achieving Sustainable Development - The Case of Serbia
}

\author{
Article history: \\ Received: 30 March 2016 \\ Sent for revision: 6 April 2016 \\ Received in revised form: 17 May 2016 \\ Accepted: 8 June 2016 \\ Available online: 8 October 2016
}

\begin{abstract}
Regional competitiveness is without doubt one of the most important component for achieving sustainability of development at local level. Capability of some region to attract investments, especially foreign, and to provide additional employment, export results and innovativeness is something that should be in the focus of development policy. On the other hand, there are different opinions about relations between macro and regional competitiveness and how to measure regional competitiveness at all. In this paper we analyze issues of regional competitiveness of regions in Republic of Serbia measured in 2008 and 2014. Differences in the position of some regions are substantial, but good performances in production, employment, income and export are not translated to better standard of living in analyzed regions. Improved position in ranking of regions does not automatically mean better life and innovativeness as ultimate goals of regional policy.
\end{abstract}

Keywords: regional competitiveness, sustainable development, regional development policy.

\footnotetext{
${ }^{1}$ Ministry of Economy, Serbia, miroljubnk@gmail.com

2 University of Belgrade, Faculty of Economics

${ }^{3}$ University of Belgrade, Faculty of Mechanical Engineering 
Nikolić M. et al.: Regional Competitiveness for Achieving Sustainable Development ...

\section{Regionalna konkurentnost u funkciji dostizanja održivog razvoja - primer Srbije}

Apstrakt: Regionalna konkurentnost je bez sumnje jedana od najvažnijih komponenti za postizanje održivosti razvoja na lokalnom nivou. Sposobnost nekog regiona da privuče investicije, naročito strane, kao i da obezbedi dodatno zapošljavanje, izvozne rezultate $i$ inovativnost je nešto što treba da bude u fokusu politike razvoja. S druge strane, postoje različita mišljenja $o$ odnosima između makro i regionalne konkurentnosti i kako meriti regionalnu konkurentnost uopšte. $U$ ovom radu se analizira regionalna konkurentnost regiona u Republici Srbiji u 2008. i 2014. godini. Razlike u položaju pojedinih regiona su značajne, ali dobri rezultati u proizvodnji, zapošljavanju, prihodu i izvozu nisu prevedeni na bolji životni standard u posmatranim regionima. Poboljšan položaj u rangiranju regiona ne znači automatski bolji život $i$ inovativnost kao krajnje ciljeve regionalne politike.

Ključne reči: regionalna konkurentnost, održivi razvoj, regionalna razvojna politika.

\section{Introductory remarks}

Entering the new millennium has made quite clear that new concepts on which the development of the world economy in this century is to be based are needed. Building the structure of the so-called "new" economy, instead of the traditional one, which is primarily based on building a knowledge economy, networking, information, innovation, and competitiveness, has started the race for global advantage on the global market. The spread of globalization and networking of business activities, not only in financial, but increasingly in the production sphere, has contributed to changes in the perception about the stakeholders on which competitiveness in a modern race relies. Contrary to the widespread opinion that the participants in the competitive race are enterprises (companies) only, and that they should fight for better position in the global game, the beginning of this century has given importance to states and their regions as competitors fighting for advantage, which has, over time, proven to be quite true (Atkinson \& Ezell, 2014).This decade has brought to the fore the concept of regional competitiveness, which is the basis of global competitiveness and the ability to achieve sustainable development of the whole country. However, just like the realization of an extremely high production growth rates over a period of time cannot be automatically classified as rapid economic development (as proven in numerous examples in sustainability analyses), mere rise on the scale of regional competitiveness is not a sign of progress in economic, especially 
Nikolić M. et al.: Regional Competitiveness for Achieving Sustainable Development ...

overall social development. In fact, it often happens that at first glance very good development results (from a purely economic point of view) do not translate into what is referred to as an increase in the living standard, quality of life, and the level of satisfaction of people in an area.

This paper will give a brief analysis and explanation related to the concept of regional competitiveness, then the ways in which it is analyzed (measured), and finally the results of application of a methodology for measuring regional competitiveness, following the case of Serbia in 2008 and 2014, with comments on development achievements contained in the concluding remarks.

\section{The Concept of Regional Competitiveness}

Most countries in the world are trying to build a modern, efficient, and competitive market economy, with a dynamic sustainable development and continuous improvement of the welfare of the population. Policy makers around the world realize that their countries must become "competitive" if they want to maintain their economic position vis-à-vis other developed or developing countries, maintain and/or improve productivity, increase investment, and develop and implement modern business models. In order to realize it, economic theorists and politicians increasingly understand the role and importance of regional competitiveness for the overall economic development and decrease in regional disproportions.

Regional competitiveness, though a popular topic among politicians and economic policy makers, is still insufficiently studied among academic researchers. For politicians and policy makers, regional competitiveness, although popular, is a rather vague umbrella concept that refers to economic development at the local government level and welfare of the population. Attention is directed to the measurement of the differences among regions, without making a clear political or conceptual framework.

The European Union promotes regions as places where it is most naturally to manage economic development, maintain adequate social policies, and protect the environment. Increase in overall competitiveness can only be achieved through improved regional competitiveness and reduced regional disproportions. This view is significant because achieving regional development requires detailed knowledge of the economic base of the region (companies, sectors, human resources, raw materials, and infrastructure resources, etc.), as well as specific regional development factors, in order to make the region more attractive for investment that increases competitiveness, economic development, and prosperity of the region. Complementarity and compliance of company strategy and operations with 
Nikolić M. et al.: Regional Competitiveness for Achieving Sustainable Development ...

the quality of the business environment is a key factor that determines regional competitiveness. The level of productivity, employment, investment, innovation, and openness of the economy, as well as the availability of highly qualified experts, are the most important factors to improve competitiveness and economic development of the region.

The expansion of the concept of competitiveness to the regional level, although recent, has a great influence on the direction of regional development policy. In particular, the development of the concept of regional competitiveness has revived the political decision-makers' interest in a new form of regional policy. In the past, regional policy sought to make regions more competitive by attracting internationally competitive companies, expecting their arrival would directly increase competitiveness and attractiveness of the region which they came to. However, this strategy had a very limited and short-lived success. It pointed to a need for a new approach to regional development, mainly based on strengthening the competitiveness of domestic enterprises. It emphasized the importance of regional "resources" as the sources of companies' competitiveness, referring not only to physical infrastructure and basic productive resources, but also to other, "soft", or less tangible (intangible) factors - the possession of superior technology, infrastructure, or institutional resources, motivated, skilled, and creative workforce, and others.

Regional competitiveness is, along with employment, the most important objective of the European Union regional policy. Accordingly, the European Union has defined program activities and areas (investment in knowledge, research and development, cooperation among scientific, research, and educational institutions and businesses, innovation, improvement of business, technological, scientific, transport and other infrastructure, etc.) for improving regional competitiveness in the European Union (European Commission, 2005).

Large regional development disparities, in addition to significantly reducing and slowing down economic growth, cause large demographic, social, security, and other problems. Therefore, in order to be sustainable, economic growth must be balanced and must cover all regions and areas in Serbia. In order to use the potentials of individual regions, cities, and municipalities, and to reduce regional disparities, it is necessary to invest in human resource development, build modern business, transport, telecommunications, health, and security infrastructure, and make rural areas sustainable. In order to achieve this, it is necessary to define the comprehensive strategic umbrella document in the field of regional development, which will be an integral part of the general development policy of long-term development of Serbia. 
Nikolić M. et al.: Regional Competitiveness for Achieving Sustainable Development ...

\section{Definition of Regional Competitiveness}

Competitiveness has become a natural law of the modern economy (Kitson, Martin \& Tyler, 2004: 991). Famous economic theorists, Schwab and Sala-iMartin, have, for the purposes of the World Economic Forum, defined national competitiveness as "a set of institutions, policies, and factors that determine the level of productivity of a country" (Schwab \& Sala-I-Martin, 2012). This definition links the micro (company level) and macro (country level) competitiveness. The analysis of competitiveness of the national economy has been a popular research subject since mid-1980s, built on the foundations of neo-liberal doctrine, known as "Reaganomics". "A nation's competitiveness is the degree to which it can, under free and fair market conditions, produce goods and services that meet the test of international markets while simultaneously expanding the real income so fits citizens. Competitiveness at the national level is based on superior productivity performance and the economy's ability to shift out put to high productivity activities which in turn can generate high levels of real wages. Competitiveness is associated with rising living standards, expanding employment opportunities, and the ability of a nation to maintain its international obligations. It is not just a measure of the nation's ability to sell abroad, and to maintain a trade equilibrium" (President's Commission on Competitiveness, 1984). The significance of the concept of national competitiveness for economic development has been accepted by both the leading theorists of economic development and major world political and development organizations and institutions, especially in the United States and the European Union. National competitiveness is seen as a reflection of competitive abilities, i.e. potentials and constraints at regional and local level. In this regard, OECD defines competitiveness "as the degree to which, under open market conditions, a country can produce goods and services that meet the test of foreign competition while simultaneously maintaining and expanding domestic real income" (OECD, 1992), and for the European Commission, "an economy is competitive if its population can enjoy high and rising standards of living and high employment on a sustainable basis. More precisely, the level of economic activity should not cause an unsustainable external balance of the economy nor should it compromise the welfare of future generations" (European Commission, 2002).

Micro competitiveness, on the other hand, shows the company's ability to compete, grow, and be profitable (Martin \& Sunley, 2006). Filo gives a similar, though slightly wider definition of micro competitiveness, claiming that competitiveness refers to the propensity and ability of companies to compete, to win and retain market position, increase market share and profitability, and ultimately strengthen commercially viable activities (Filó, 2007).The previous 
Nikolić M. et al.: Regional Competitiveness for Achieving Sustainable Development ...

two definitions show that micro competitiveness implies the ability of companies to continuously and profitably manufacture products and provide services that meet the requirements of the open market in terms of price, volume, quality, deadlines, etc., and that more competitive companies operate more successfully and displace less competitive companies from the market.

However, establishing a direct analogy between micro (company level) and macro (country level) competitiveness has been criticized by authors such as Krugman, because countries cannot cease to compete (and still have to do business), with the benefits of competition available to both countries, while competition between companies on the same territory is often a zero-sum game (more competitive company displaces less competitive company) (Krugman, 1996). Therefore, between the micro and macro concept of competitiveness there is the concept of regional competitiveness, and regions are becoming the center of focus and sources of competitive advantage and economic power.

Regional competitiveness has been the subject of debates on the definition of the concept (whether regional competitiveness is, in fact, the sum of competitiveness of a group of companies, or is it a derivative of macroeconomic competitiveness (in that regard, Gardiner points out that regions are neither a simple sum of companies, nor a condensed version of the country) (Gardiner, Martin \& Tyler, 2004), or at the same time a reflection of the micro and macro aspects that define it) and on its determinants and measurement. Some authors, such as Boschma, also ask the question of whether regions can really compete (Boschma, 2004).

Since the late 1990s, in the European Union, defining competitiveness has taken the regional aspect into account as well, where competitiveness itself is defined" as the ability to produce goods and services which meet the test of international markets, while at the sametime maintaining high and sustainable levels of income or, more generally, the ability of (regions) to generate, while being exposed to external competition, relatively high income and employment levels", or "in other words, for a region to be competitive, it is important to ensure both quality and quantity of jobs" (Commission of the European communities, 1999: 75). Accordingly, the region is competitive if it can attract and retain successful companies, educated (skilled) workers, and investment, and provide or improve living standard for all inhabitants of the region. The notion of regional competitiveness has expanded over time, so that it includes the ability of the region to create a sufficient level of exports to achieve a sustainable level of income (full employment) of the population, and, in addition to quantitative, includes qualitative factors, implying that competitiveness is seen as an aggregate influence of several factors, the most important being the development and availability of business and other 
Nikolić M. et al.: Regional Competitiveness for Achieving Sustainable Development ...

infrastructure, availability and quality of human resources, production environment, etc. (European Commission, 2004).

Kitson et al. suggests that even though politicians often use the term 'regional competitiveness', it remains 'complex and contentious', and 'we are far from a consensus on what is meant by the term' (Kitson et al., 2004: 992). This is confirmed by a number of definitions and perceptions of regional competitiveness that can be found in literature. For example, Huggins believes that regional competitiveness relates to the presence of conditions that allow companies to compete on the selected markets and to create value within a given region (Huggins, 2003). Kitson et al. define regional competitiveness as a competitive advantage of a region in relation to another region, seen through the participation (national and international) in the export market (Kitson et al., 2004: 992). Storper specifies that regional competitiveness implies the ability of the region to attract and retain companies with stable or growing share on a particular market, while maintaining stable or increasing living standard for those who participate in it (Storper, 1997). Following this approach, Audretsch and Keilbach suggest that competitiveness can vary across geographic area, where regions are developing at different speeds depending on the driver of growth (Audretsch \& Keilbach, 2004).

According to Meyer, "regional competitiveness can be defined as the ability of a region to realize high and rising income and improve the living standard of people who live in it" (Meyer-Stamer, 2008). This definition is based solely on the benefits of people who live in the region, and assumes a close relationship between competitiveness and prosperity. In this regard, regional competitiveness is not observed from the perspective of productivity, but through sustainability or rising level of prosperity compared to other regions (Bristow, 2005). Taking into account the previous points of view, the definition of regional competitiveness was proposed, which integrates both approaches, from the perspective of companies (productivity) and from the perspective of the population (prosperity).

Dijkstra defines regional competitiveness as the ability of the region to offer attractive and sustainable environment for businesses and people to live and work in it (Dijkstra, Annoni \& Kozovska, 2011). Sustainability in this definition relates to the capacity of the region to provide an attractive business and living environment in both the short and long term. This means that the region that reduces taxes to the extent that it can no longer maintain the quality of its public infrastructure and public services does not provide a viable and attractive environment. This definition encompasses issues that are important for both the companies and the population, such as efficient institutions, as well as issues where their interests may conflict, such as wages. In that regard, there are attempts to establish a balance among the most important 
Nikolić M. et al.: Regional Competitiveness for Achieving Sustainable Development ...

factors that determine the attractiveness of the environment, by combining the goals of commercial success and personal well-being.

For regions it is important that competitiveness does not only increase the market share of companies within a particular activity or market, but also that it increases, or, at least, maintains the same level of living standard, as this should be the ultimate goal of improving competitiveness (Aiginger, 2006). In general, regional development refers to the improvement of economic, institutional, and social bases, which allows for the development of entrepreneurship relying on the development potentials of the region (Amin, 1999). Accordingly, a number of authors believe that entrepreneurship is the center of regional economic growth and competitiveness (Audretsch \& Keilbach, 2004 and Malecki, 2007). Andersson holds a similar view, highlighting the importance of entrepreneurship, and suggesting that the regional economy that does not include factors of entrepreneurship may not be able to understand and identify key sources of regional development (Andersson \& Karlsson, 2007). Benneworth indicates that open and creative regions can attract and retain human resources and facilitate the development of dynamic entrepreneurship (Benneworth, 2004).

Camagni is one of the theorists who believe that the concept of regional competitiveness is theoretically correct, because of the role that the region has in ensuring competitive conditions for companies' business and in the process of accumulation of knowledge (Camagni, 2002). Similar understanding of regional competitiveness was given by Krugman, claiming that regional competitiveness is based on its ability to provide sufficiently attractive wages and/or conditions for employment and return on equity (Krugman, 2003). Bristow's perspective is interesting too, stating that, despite accusations that regional competitiveness emerged on the basis of neo-liberal ideology (the so-called Reaganomics), the concept neither assumes nor supports the minimal role of the state (Bristow, 2010).

Despite the fact that a single theoretical perspective that combines all the elements of the complex concept of regional competitiveness has not been developed yet, for the purposes of this paper, regional competitiveness shall mean the ability of the region to, in conditions of domestic and international competition, create an attractive business environment for new investment and development of entrepreneurship, and, on this basis, provide relatively high income, employment, and overall well-being of the population. Therefore, a simple definition of regional competitiveness has been adopted, which pragmatically responds to the current issues raised in literature, and makes it possible to select the most appropriate indicators for measuring the achieved level and changes in regional competitiveness.

This paper aims to set up a regional discourse on competitiveness in the context of theories of regional economic growth and stages of economic 
Nikolić M. et al.: Regional Competitiveness for Achieving Sustainable Development ...

development. This positions the concept of regional competitiveness, as well as models for its measurement, within theories that try to understand and identify ways in which economic growth manifests itself in the regions. In order to achieve this, the paper starts with the most important theoretical and methodological achievements in this field, which provides for the clearer determination and more precise measurement of the concept of regional competitiveness, taking into account the level of development of the national economy, regional specifics, and availability of data. This approach allows for the analysis of different sources and carriers of regional competitiveness, and provides a tool for research into the development and results of regional competitiveness, as the basis for regional development of the national economy.

\section{Measuring Regional Competitiveness}

Empirical studies of regional competitiveness have used different approaches, depending on the definition and understanding of the concept of regional competitiveness, the level of regional development, and the availability of data. Generally speaking, one of the approaches to the analysis of regional competitiveness is based on identifying and measuring individual and joint factors of competitiveness, while the second approach is based on the analysis of the results of regional competitiveness. Since competitiveness is a complex phenomenon, combined approach is increasingly applied in practice, which includes elements of the previous two approaches, integrated into a single aggregate index of regional competitiveness.

Authors such as Porter (Porter, 1990) and Krugman (Krugman, 1994), and later Armstrong and Taylor (Armstrong \& Taylor, 2006), believe that productivity is the best measure of competitiveness, and that the level and pace of productivity changes within the regional competitiveness model is the best indicator of regional competitiveness.

Great Britain has, as part of research for the British government, expanded a methodological concept of measuring regional competitiveness, with the main determinants of regional competitiveness being: level of education, innovation capacity, participation of employees in industries with high added value, development of financial and business services, overall level and share of foreign direct investment (United Kingdom Department of Trade and Industry, 1997).

Similarly, the research conducted for the European Commission states the following as indicators that mostly influence regional competitiveness: employment and productivity levels of employees, level of employment by sector, demographic trends, investment, investment in knowledge, 
Nikolić M. et al.: Regional Competitiveness for Achieving Sustainable Development ...

infrastructure development, quality and type of education, innovation and research and development (European Commission, 2001).

The study conducted in Wales in 2002further develops the methodology for analyzing and measuring regional competitiveness, where the most important factors of regional competitiveness include strong institutional orientation, specialization, focus of public and private sector on development activities, with emphasis on the importance of long-term sustainability of cultural factors (Barclays Bank, 2002). A large number of other authors also point to the importance of the so-called soft factors (knowledge, learning, creativity) in their studies of regional competitiveness (Florida, 2002 and Malecki, 2002).

Gardiner classifies indicators of regional competitiveness into competitiveness measures (production indicators) and factors that contribute to their success (input factors - development, quality and availability of infrastructure, availability, cost, and quality of human resources, importance of institutions, and a number of other factors, such as research and development, innovation, demography, etc.) (Gardiner, 2003).

In its research, OECD also provides an overview of the factors of regional competitiveness. OECD measures economic strength as the difference among intermediate levels of GDP per capita in the region, as well as at the average level of the economy, as a result of average labor productivity (productivity of regional production), industrial specialization (the impact of higher education on GDP), skills (human capital participation), employment rate (efficiency of the local labor market), migration (impact of geographic location), aging (influence of age on the participation rate), and rate of activity (characteristics of the regional labor force) (OECD, 2005).

Lengyel and Lukovics focus on the case of Hungary, and analyze regional competitiveness on the basis of indicators such as GDP per capita, labor productivity, employment rate, and openness of the economy (Lengyel \& Lukovics, 2006). Huggins and Davis have gone a step further in the measurement of regional competitiveness, by creating a European Competitiveness Index, on the basis of which they measure competitiveness of 118 regions in 27 countries of the European Union. The index emphasizes the importance of regional aspects of competitiveness and the role of knowledge, creativity, and infrastructure in the analysis of regional competitiveness (Huggins \& Davies, 2006). Based on the weighting of different components of competitiveness developed by Huggins, Bronisz, Heijman, and Miszczuk have developed an index of regional competitiveness of Poland, based on which they ranked 16 Polish regions according to their competitiveness (Bronisz, Heijman \& Miszczuk, 2008).

Measuring regional competitiveness in Serbia is insufficiently explored, and scarce research in this area (Research in this field in Serbia has been 
Nikolić M. et al.: Regional Competitiveness for Achieving Sustainable Development ...

conducted within Republic Institute for Development, now Ministry of the Economy) is mostly focused on the analysis of individual determinants of competitiveness in order to increase regional competitiveness and reduce regional disproportions, because previous work in this area has pointed to the existence of uneven regional development and, consequently, very uneven level of competitiveness among different regions in Serbia.

Starting from the above theoretical and methodological framework, the level of development of the Serbian economy, the results of previous research (Ministry of Economy, 2015), and the availability of data, for the purposes of the research, the regional competitiveness index has been constructed, which includes eight pillars (elements) of regional competitiveness (number of employees, GVA, exports, investment in new equipment and intellectual property, highly educated people in relation to a thousand inhabitants, unit labor costs, market activity of the entrepreneurial sector, and entrepreneurial dynamics). It allows for the identification and measurement of different factors (sources) of regional competitiveness and their individual and aggregate influence on regional competitiveness, making it possible to determine the level of competitiveness of each region in Serbia and the ranking of regions according to the level of competitiveness, identify strengths and weaknesses in building competitiveness, and provide suggestions for strengthening and improving the competitiveness of individual regions in Serbia and competitiveness of the Serbian economy as a whole.

\section{Methodological Framework}

DTF (Distance to frontier) is scoring on a scale of 0 to 1.00 (where 1.00 is the best score, i.e. the aspired frontier, and 0 the weakest result - the worst performance), which points to the distance of some districts in relation to the district that achieves the best results (performance) in an area in the year observed.

DTF allows for the analysis of backwardness (lag or gap) in the performance of some district in relation to the district with the best performance at any time, and for the assessment of the absolute change in the regional competitiveness of the economy over time, as well as the ranking of districts according to the level of regional competitiveness. For example, a score of 0.75 in 2014 indicates that some district was 25 percentage points behind the best region in a given area in 2014. A score of 0.80 in 2015 indicates that the gap between the district and the best district decreased compared to the previous year.

The ranking of districts uses the value of the composite indicator - regional development index, based on the scores of distance from the performance in 
Nikolić M. et al.: Regional Competitiveness for Achieving Sustainable Development ...

8 fields (number of employees per thousand inhabitants; GVA per capita in 000 RSD; exports per capita in 000 RSD, investment in new equipment and intellectual property per capita in 000 RSD; highly educated people per 1000 inhabitants; unit labor costs - ULC; market activity of the entrepreneurial sector; and entrepreneurial dynamics), and shows how much each district is close to the best (most developed) district. Higher scores indicate better business and development performance and greater regional competitiveness.

The ranking of districts by the aggregate regional development index, as well as all rankings of individual competitiveness indicators (number of employees per thousand inhabitants; GVA per capita in 000 RSD; exports per capita in 000 RSD; highly educated people per 1,000 inhabitants; etc.) are calculated on the basis of the value of DTF indicator (distance to frontier - distance from the district with the best performance).

Unlike the ranking, the value of DTF shows the absolute distance of district performance from the best performance by aggregate and/or each individual indicator of the regional competitiveness index. Broken down by years, the value of DTF shows the absolute changes in regional competitiveness of individual districts, while, on the other hand, change in the ranking shows changes in regional competitiveness among individual regions.

Regional competitiveness index calculation is carried out in stages:

(1) The value of each regional competitiveness indicator (xn) for all districts is normalized through the linear transformation:

$$
(\mathrm{xmin}-\mathrm{xn}) /(\mathrm{xmin}-\mathrm{xmax})
$$

xmax - the maximum (limit) value of the indicator, $x \min$ - minimum value of the indicator,

so that the value of each individual indicator of regional competitiveness is reduced to mutually comparable value units - DTF (taking values from 0 to 1.00 , where 0 is the worst and 1,00 the best performance).

(2) Aggregate regional competitiveness indicator (regional development index) for each district is calculated by aggregating DTF (method of simple arithmetic mean) of all individual regional competitiveness indicators. In this way, each element of regional competitiveness has the same weight, i.e. the same importance in measuring the overall competitiveness of the district.

(3) The ranking of regional competitiveness is done by sorting districts by aggregate value of the regional competitiveness index (average values of DTF by all 8 individual regional competitiveness indicators). 
Nikolić M. et al.: Regional Competitiveness for Achieving Sustainable Development ...

(4) Classification of districts according to the levels of competitiveness (five levels of regional competitiveness) is done by grouping the normalized values of the aggregate regional competitiveness index for each district separately, where each district is classified into one of five groups of regional competitiveness.

Table 1. Regional competitiveness in Serbia, in 2008 and 2014

\begin{tabular}{|c|c|c|c|c|c|c|}
\hline \multirow[t]{2}{*}{ District } & \multicolumn{2}{|c|}{$\begin{array}{c}\text { Regional } \\
\text { competitiveness } \\
\text { index }\end{array}$} & \multicolumn{2}{|c|}{ District ranking** } & \multicolumn{2}{|c|}{$\begin{array}{c}\text { Level of } \\
\text { competitiveness }^{* * *}\end{array}$} \\
\hline & 2008 & 2014 & 2008 & 2014 & 2008 & 2014 \\
\hline Belgrade district & 0,66 & 0,70 & 1 & 1 & 1 & 1 \\
\hline North Bačka district & 0,34 & 0,37 & 3 & 8 & III & III \\
\hline West Bačka district & 0,32 & 0,24 & 5 & 21 & III & IV \\
\hline South Bačka district & 0,51 & 0,56 & 2 & 3 & II & II \\
\hline North Banat district & 0,20 & 0,33 & 19 & 10 & IV & IV \\
\hline Central Banat district & 0,22 & 0,30 & 15 & 14 & IV & IV \\
\hline South Banat district & 0,20 & 0,35 & 17 & 9 & IV & IV \\
\hline Srem district & 0,26 & 0,38 & 9 & 6 & IV & III \\
\hline Mačva district & 0,20 & 0,28 & 16 & 16 & IV & IV \\
\hline Kolubara district & 0,19 & 0,28 & 21 & 17 & $\mathrm{~V}$ & IV \\
\hline Šumadija district & 0,24 & 0,63 & 12 & 2 & IV & 1 \\
\hline Pomoravlje district & 0,20 & 0,29 & 18 & 15 & IV & IV \\
\hline Zlatibor district & 0,27 & 0,37 & 8 & 7 & IV & III \\
\hline Moravica district & 0,30 & 0,31 & 6 & 13 & IV & IV \\
\hline Raška district & 0,22 & 0,27 & 13 & 18 & IV & IV \\
\hline Rasina district & 0,18 & 0,26 & 22 & 19 & $\mathrm{~V}$ & IV \\
\hline Podunavlje district & 0,33 & 0,11 & 4 & 25 & III & $\mathrm{V}$ \\
\hline Braničevo district & 0,25 & 0,32 & 10 & 12 & IV & IV \\
\hline Bor district & 0,30 & 0,47 & 7 & 4 & IV & II \\
\hline Zaječar district & 0,10 & 0,21 & 24 & 23 & $\mathrm{~V}$ & $\mathrm{~V}$ \\
\hline Nišava district & 0,24 & 0,32 & 11 & 11 & IV & IV \\
\hline Toplica district & 0,07 & 0,26 & 25 & 20 & $\mathrm{~V}$ & IV \\
\hline Pirot district & 0,22 & 0,43 & 14 & 5 & IV & III \\
\hline Jablanica district & 0,20 & 0,23 & 20 & 22 & IV & IV \\
\hline Pčinja district & 0,13 & 0,18 & 23 & 24 & $\mathrm{~V}$ & $\mathrm{~V}$ \\
\hline \multicolumn{7}{|c|}{$\begin{array}{l}\text { *The regional competitiveness index is calculated as the average value of DTF (distance to } \\
\text { frontier) in respect of eight regional competitiveness indicators. } \\
{ }^{* *} \text { The ranking of competitiveness is done by sorting the districts according to the value of the } \\
\text { regional competitiveness index ( } 1 \text { to } 25 \text { ). } \\
\text { *** The level of competitiveness is determined by grouping the normalized values of the index } \\
\text { of regional competitiveness, so that each district is classified into one of five groups of regional } \\
\text { competitiveness. }\end{array}$} \\
\hline
\end{tabular}

Source: Calculation of the author, according to the data from Statistical Office of the Republic of Serbia 
Nikolić M. et al.: Regional Competitiveness for Achieving Sustainable Development ...

\section{Results of the Applied Analysis}

Table 1 shows that several districts have recorded significant changes (for better or for worse), as a result of activities undertaken (or lacking) in the given period. In addition, the extreme cases are Šumadija, in the positive sense, and West Bačka and Podunavlje, in the negative sense. The first moved from the 12th position in 2008 to the 2nd in 2014, just behind the "indisputable" Belgrade district, while the second and the third recorded a drop by as much as 16 places, from the 5 th to the 21 st, i.e. by 21 places, from the $4^{\text {th }}$ to the $25^{\text {th }}$ position, respectively, and from III to IV, i.e. from III to V group of regions, grouped according to competitiveness. The remainder of this paper analyzes briefly the case of drastic (nominal) improvement of the competitive position of the region, and what it means in practice for its population, i.e. whether the results of the growth in production and exports of the region have really transformed into the development, measured primarily by improved living standards and other life quality indicators in a local community.

Although Šumadija district recorded the greatest increase in regional competitiveness in 2014 compared to 2008 , and moved from the fourth group of districts with very low regional competitiveness to the first group of districts with the best regional competitiveness in Serbia (thus joining Belgrade, which kept the leaderhip position in Serbia), this was not reflected in the strengthening of the purchasing power, living standard, and the welfare of the local population.

In 2014, the number of employees in Šumadija district, compared to 2008, decreased by 5,235 (from 51,738 to 46,503 ), i.e. by $1.8 \%$ on average per year. The fall in employment was accompanied by a decline in real wages (costs of wages, i.e. gross wages) - the annual value of wages decreased by 4.4 billion dinars (from 42.3 in 2008 to 37.9 billion dinars in 2014), i.e. by about $1.8 \%$ a year in real terms. Decline in the value of wages, accompanied by a fall in employment, has led to a decline in average real wages (wage per employee) - in 2014, the average annual wage in real terms fell by 3,100 dinars (from 818.0 to 814.9 thousand RSD), i.e. the average annual decline in average wages amounted to $0.1 \%$, which, together with a decline in employment, caused a significant decline in purchasing power, living standard, and the welfare of the population in Sumadija district, despite the strong growth of the regional competitiveness of the local economy. 
Nikolić M. et al.: Regional Competitiveness for Achieving Sustainable Development ...

Table 2. Trends in average wages in the selected areas of the Republic of Serbia from 2010 to 2014

- In RSD -

\begin{tabular}{|l|c|c|c|c|c|}
\hline \multicolumn{1}{|c|}{ Region } & 2010 & 2011 & 2012 & 2013 & 2014 \\
\hline Republic of Serbia & 34,142 & 37,976 & 41,377 & 43,932 & 44,530 \\
\hline Belgrade & 42,489 & 46,986 & 51,121 & 54,103 & 55,429 \\
\hline $\begin{array}{l}\text { Regions of Šumadija and Western } \\
\text { Serbia }\end{array}$ & 28,636 & 32,175 & 34,981 & 37,425 & 37,504 \\
\hline Šumadija region & 30,119 & 34,411 & 37,110 & 40,372 & 39,920 \\
\hline Kragujevac & 31,570 & 36,918 & 39,282 & 43,011 & 41,744 \\
\hline Kragujevac in relation to Serbia in \% & 92.5 & 97.2 & 94.9 & 97.9 & 93.7 \\
\hline
\end{tabular}

Source: The authors, according to the data from Statistical Office of the Republic of Serbia

The growth of regional competitiveness, accompanied by a fall of well-being of the population, according to many authors, is not a real increase in regional competitiveness, but a structural adjustment of the local economy, without sustainable economic growth (growth based on strengthening regional competitiveness) and increase in total welfare on that basis.

As seen in the tables attached, an increase in regional competitiveness of Šumadija district in the reporting period was based on the following factors:

The basis is an increase in investment in new equipment and intellectual property, as a prerequisite for the realization of production growth. This indicator at the level of the Republic of Serbia recorded a slight decline from 2008 to 2014 (from 36 to 35 thousand dinars per capita per year), while Šumadija district recorded more than triple increase (from 20 to 68). Certainly, it should be borne in mind that a good portion of this investment was financed by the Republic of Serbia, which partly spoils the impression of this indicator.

Investment undertaken has resulted in a drastic jump of the gross value added per capita (GVA) and exports per capita. Indicators in the same years (2008 and 2014) had the values of 125 and 258 in respect of GVA, and 47 and even 715 in respect of exports! The same indicators at the level of the Republic of Serbia recorded a value of 193 and 258 in respect of GVA, and 81 and 181 in respect of exports. Thus, according to the level of GVA, Šumadija district equalled the average of the Republic, while by exports, it was nearly four times better than the average.

Contribution to the growth of competitiveness of Šumadija region has undoubtedly been made by an increase in indicator of the number of highly educated persons per thousand inhabitants, which, in the reporting period, increased from 80 to 124 , and thus significantly reduced the gap between that district and the average of the Republic (93 and 146 in the same years). 
Nikolić M. et al.: Regional Competitiveness for Achieving Sustainable Development ...

Finally, the indicators that positively contributed to increase in the competitiveness of Šumadija region include lower unit labor costs (ULC), obtained as the ratio of totally paid wages and realized GVA. In 2008 and 2014, they amounted to 0.76 and 0.51 , while at the Republic level, they were 0.62 and 0.61 .

\section{Concluding Remarks}

So, more than the doubled GVA, with a simultaneous decline in total employment (from 178 to 161 employees per thousand inhabitants), contributed to the extreme rise in productivity and competitiveness of the region, not only on the domestic market, but also in international terms, which allowed a high level of exports. However, this was not reflected in employment, wages of employees, and the general increase in the living standards in Kragujevac and surrounding areas, which calls into question the sustainability of the results achieved in terms of production growth in the long term.

The period 2015-2016, with its gradual but constant decline in the pace of production and demand for the basic product of Šumadija district (cars), pointed to the necessity of entry into a new investment cycle, in order to further enhance regional competitiveness. However, sustainability of growth and development in the future requires investment in far more innovative and technologically superior products, so that the results of investment and production could translate into a substantial increase in living standard, with the maintenance of the competitive position of the region in the international race for advantage.

Starting from the attitudes of the famous M. Porter, which this author made back in his book Competition in Global Industries in the mid-1980s, based on which traditional sources of competitive advantage are completely unreliable and unsustainable because they constantly change, some specific measures will be proposed here. The starting point will be his idea that factors such as "low-cost unskilled labor" and natural resources - are less and less important for global competitiveness in relation to complex factors, such as higher scientific and technical support of workers and advanced infrastructure, particularly information infrastructure. In this sense, the following measures are proposed:

- More directly involve science, research, and education in the development of the industry;

- Continuously stimulate the development of the information society and strengthening of infrastructure; 
Nikolić M. et al.: Regional Competitiveness for Achieving Sustainable Development ...

- Accelerate the transfer of knowledge (academic, managerial, etc.) and technology into production, as a strong factor of competitiveness;

- Raise the level of innovation in all spheres of life: create "hunger" for innovation, promote innovators as particularly important "heroes of our time";

- Stimulate in particular every aspect of production creativity and innovation, through state scholarships, attractive one-time awards, permanent foundations, and the like;

- Legally regulate the state as a system of responsible structures of legislative, executive, and judicial authorities, in order to eradicate corruption, grey economy, and crime;

- Reduce the costs of public administration, increase its effectiveness ("guillotine of regulations"), as well as the effectiveness of public services and local government;

- Stabilize the monetary and fiscal policy to stimulate production investment. Tax policy must be open in the function of reindustrialization. Decrease parafiscal levies for investors;

- Increase rationality and control of the banking sector to make it more in the function of liquidity and investment expansion of the economy, primarily in the function of reindustrialization. The banking sector should not be more important than production/industrial sector;

- Encourage export orientation of the economy through better use of the comparative advantages that, together with the new technology, can bring strong competitive advantage;

- Improve energy efficiency in the whole society through measures of new energy policy.

We are confident that the implementation of even a part of these measures will strongly contribute to the regional competitiveness and sustainable development of Serbia.

\section{References}

Aiginger, K. (2006). Competitiveness: From a Dangerous Obsession to a Welfare Creating Ability with Positive Externalities. Journal of Industry, Competition and Trade, 6(2), 161-177. doi:10.1007/s10842-006-9475-6

Amin, A. (1999). An institutionalist perspective on regional economic development. International Journal of Urban and Regional Research, 23(2), 365378. doi:10.1111/1468-2427.00201

Andersson, M., \& Karlsson, C. (2007). Knowledge in regional economic growth: The role of knowledge accessibility. Industry and Innovation, 14, 129-149.

Armstrong, H., \& Taylor, J. (2006). Regional Economics and Policy. United Kingdom: Blackwell Publishing. 
Nikolić M. et al.: Regional Competitiveness for Achieving Sustainable Development ...

Atkinson, R.D., \& Ezell, S.J. (2014). Ekonomika inovacija - utrka za globalnu prednost, prevod. Zagreb: MATE d. o. o..

Audretsch, D.B., \& Keilbach, M. (2004). Entrepreneurship and regional growth: An evolutionary interpretation. Journal of Evolutionary Economics, 14(5), 605-616. doi:10.1007/s00191-004-0228-6

Barclays, B.P.L.C. (2002). Welsh Development Agency and English Regional Development Agency, Competing with the World. Retrieved from http://www.newsroom.barclays.com/imagelibrary/detail.asp?MediaDetailsID=498 9.

Benneworth, P. (2004). In what sense regional development?, Entrepreneurship, underdevelopment and strong tradition in the periphery. Entrepreneurship and Regional Development, 16(6), 439-458.

Boschma, R.A. (2004). The Competitiveness of Regions from an Evolutionary Perspective. Regional Studies, 38(9), 1001-1014.

Bristow, G. (2005). Everyone's a 'winner': Problematizing the discourse of regional competitiveness. Journal of Economic Geography, 5, 285-304.

Bristow, G. (2010). Critical Reflections on Regional Competitiveness. London: Routledge.

Bronisz, U., Heijman, W., \& Miszczuk, A. (2008). Regional Competitiveness in Poland: Creating an index. Jahrbuch für Regional wissenschaft, 28(2), 133-143. Retrieved from http://www.springerlink.com/content/r22h8073t7243782/fulltext.pdf.

Camagni, R. (2002). On the concept of territorial competitiveness: Sound or misleading?. Urban Studies, 39, 2395-2411.

-Commission of the European communities. (1999). Regional Policy and Cohesion Sixth Periodic Report on the Social and Economic Situation and Development of the Regions of the European Union. Brussels. SEC 66 final.

Dijkstra, L., Annoni, P., \& Kozovska, K. (2011). A new regional competitiveness index: Theory, Methods and Findings. European Union Regional Policy Working Papers, 2,

-European Commission. (2001). Second Report on Economic and Social Cohesion. Retrieved from http://ec.europa.eu/regional_policy/sources/docoffi c/official/reports/contentpdfen.htm

-European Commission. (2002). European Competitiveness Report. Luxembourg: European Communities, Office for Official Publications of the European Communities.

-European Commission. (2004). A New Partnership for Cohesion: Convergence, Competitiveness, Cooperation, Third Cohesion Report on Economic and Social Cohesion. Brussels.

-European Commission. (2005). Cohesion Policy in Support of Growth and Jobs: Community Strategy Guidelines 2007-2013. Retrieved from http://ec.europa.eu/regional_policy/sources/docoffic/2007/osc/050706osc_en.pdf

Filó, C. (2007). Territorial Competitiveness and the Human Factors. In: Presented at the International Conference of Territorial Intelligence, (CAENTI), Huelva. Retrieved from http://www.territorial-intelligence.eu

Florida, R. (2002). The economic geography of talent. Annals of the Association of American Geographers, 4(92), 743-755. 
Nikolić M. et al.: Regional Competitiveness for Achieving Sustainable Development ...

Gardiner, B. (2003). Regional Competitiveness Indicators for Europe: Adit, Database Construction and Analysis. Retrieved from http://www.camecon.com/economic_intelligence_services/eu_regional/download able_files/Regional\%20

Gardiner, B., Martin, R., \& Tyler, P. (2004). Competitiveness, Productivity and Economic Growth across the European Regions. Regional Studies, 38, 10451067.

Huggins, R., \& Davies, W. (2006). European Competitiveness Index 2006-2007. Retrieved from http://www.cforic.org/pages/european-competitiveness.php.

Huggins, R. (2003). Creating a UK Competitiveness Index: Regional and Local Benchmarking. Regional Studies, 37, 89-96.

Kitson, M., Martin, R., \& Tyler, P. (2004). Regional Competitiveness: An Elusive yet Key Concept?. Regional Studies, 9(38), 991-999.

Krugman, P. (1994). Competitiveness: A dangerous obsession. Foreign Affairs, 73, 28 44.

Krugman, P. (1996). Making sense of the competitiveness debate. Oxford Review of Economic Policy, 12(3), 17-25.

Krugman, P. (2003). Growth on the Periphery: Second Wind for Industrial Regions?. Glasgow, UK: Fraser Allander Institute.

Lengyel, I., \& Lukovics, M. (2006). An Attempt for the Measurement of Regional Competitiveness in Hungary. Retrieved from http://www.ersa.org/ersaconfs/ersa06/papers/350.pdf.

Malecki, E.J. (2002). Hard and Soft Networks for Urban Competitiveness. Urban Studies, 39(5-6), 929-945.

Malecki, E.J. (2007). Cities and regions competing in the global economy: Knowledge and local development policies. Environment and Planning C Government and Policy, 25(3), 638-654.

Martin, R., \& Sunley, P. (2006). Path dependence and regional economic evolution. Journal of Economic Geography, 6(4), 395-437.

Meyer-Stamer, J. (2008). Systematic Competitiveness and Local Economic Development. In S. Bodhanya (Ed.), Large Scale Systemic Change: Theories, Modelling and Practices.

-Ministry of Economy. (2015). Report on Regional Development of Serbia 2014. Department for Regional Development and Strategic Analyses of the Economy.

-OECD. (1992). Programme on Technology and the Economy. Paris.

-OECD. (2005). Regions at a Glance. Paris.

-OECD. (2007). Regions at a Glance. Paris.

Porter, M. (1986). Competition in Global Industries. Harvard Business School.

Porter, M. (1990). The Competitive Advantage of Nations. London: Macmillan.

-President's Commissionon Competitiveness. (1984). The Report of the President's Commission on Competitiveness, written for the Reagan administration.

Schwab, K., \& Sala-I-Martin, X. (2012). The Global Competitiveness Report 20122013. World Economic Forum. Retrieved from http://www3.weforum.org/docs/WEF_GlobalCompetitivenessReport_2012-13.pdf

-Statistical Office of the Republic of Serbia. Employment and wages database. Retrieved from http://webrzs.stat.gov.rs/WebSite/public/ReportView.aspx

Storper, M. (1997). The Regional World. New York: Guilford Press. 
Nikolić M. et al.: Regional Competitiveness for Achieving Sustainable Development ...

-United Kingdom Department of Trade and Industry. (1997). Regional Competitiveness Indicators, East and West Midlands Benchmark. London: Government Statistical Service. 